\title{
Comparative morphology of gill glands in externally fertilizing and inseminating species of cheirodontine fishes, with implications on the phylogeny of the family Characidae (Actinopterygii: Characiformes)
}

\author{
Cristina L. C. de Oliveira ${ }^{1}$, Luiz R. Malabarba² and John R. Burns ${ }^{3}$
}

The structure and form of gill gland among inseminating and externally fertilizing species of the Cheirodontinae are described under light microscopy, scanning electron microscopy, and transmission electron microscopy, and compared to other members of the family Characidae. At least one species from thirteen cheirodontine genera were analyzed, totaling seventeen species. Gill glands were found in all analyzed mature males of Cheirodontinae and were always absent in females, being located on the anteriormost portion of the lower branch of the first gill arch, extending posteriorly through a variable number of gill filaments. Gill glands of all cheirodontines and of all characid species in which this organ has been described possess the same structure, being considered homologous and supporting a single origin of the structure in a common ancestor to Clade A and Clade B characids.

A estrutura e forma da glândula branquial de queirodontíneos inseminadores e de fecundação externa são descritas com base em análises de microscopia óptica, microscopia eletrônica de varredura e microscopia eletrônica de transmissão, e comparadas com outros membros da família Characidae. Pelo menos uma espécie de treze gêneros de Cheirodontinae foram analisadas, num total de dezessete espécies. Glândulas branquiais foram encontradas em todos os machos maduros analisados de Cheirodontinae, localizadas na parte mais anterior do ramo inferior do primeiro arco branquial, estendendo-se posteriormente por um número variável de filamentos branquiais, estando sempre ausentes nas fêmeas. As glândulas branquiais de todos os queirodontíneos analisados e de todas as espécies de Characidae em que este órgão foi descrito possuem a mesma estrutura, sendo consideradas homólogas e suportando uma origem única em um ancestral comum aos Clados A e B de Characidae.

Key words: Characid clade A, Characid clade B, Gill filaments, Gill secondary lamellae.

\section{Introduction}

The subfamily Cheirodontinae consists of 16 genera and approximately 54 species (Malabarba, 2003; Bührnheim et al., 2008), currently arranged into two tribes, Compsurini (including the genera Acinocheirodon, Compsura, Kolpotocheirodon, Macropsobrycon, and Saccoderma), and Cheirodontini (including the genera Amazonspinther, Cheirodon, Heterocheirodon, Nanocheirodon, Serrapinnus, and Spintherobolus), in addition to five genera of uncertain phylogenetic position within the subfamily (Aphyocheirodon, Cheirodontops, Odontostilbe, Prodontocharax, and Pseudocheirodon).
Species within Cheirodontini and the incertae sedis genera are all externally fertilizing, whereas those within Compsurini are all inseminating, as observed by the presence of spermatozoa in their ovaries (Burns et al., 1997; Malabarba, 1998). The timing of fertilization in inseminating species, however, is unknown since no fertilized eggs have been observed in the ovaries (Burns et al., 1997, 1998; Burns \& Weitzman, 2005). In addition to the Cheirodontinae, insemination has also been confirmed in all species within the subfamilies Glandulocaudinae and Stevardiinae (sensu Weitzman et al., 2005 and Menezes \& Weitzman, 2009), and in several characid genera of uncertain affinities (Javonillo et al., 2009).

\footnotetext{
${ }^{1}$ Universidade Estadual de Santa Cruz, Departamento de Ciências Biológicas, Rodovia Ilhéus-Itabuna km 16, $45662-900$ Ilhéus, Bahia, Brazil.crisbio2@gmail.com

${ }^{2}$ Universidade Federal do Rio Grande do Sul, Departamento de Zoologia, IB, Av. Bento Gonçalves, 9500, 91501-970 Porto Alegre, Rio Grande do Sul, Brazil.malabarb@ufrgs.br

${ }^{3}$ George Washington University, Department of Biological Sciences, Washington, D.C. 20052, USA.jrburns@gwu.edu
} 
Inseminating male characids often have hypertrophied tissues, that appear to be glandular, at discrete sites on the body. Such tissues have been described on the caudal fin of the compsurin cheirodontines Acinocheirodon melanogramma (see Malabarba \& Weitzman, 1999), Kolpotocheirodon theloura and Kolpotocheirodon figueiredoi (see Malabarba \& Weitzman, 2000; Malabarba et al., 2004) and on the caudal fin of glandulocaudines and stevardiines (see Weitzman et al., 2005; Menezes \& Weitzman, 2009). The fact that these hypertrophied tissues are restricted to mature males has been used to suggest that some components of the gland secretions may be used as chemical signals, perhaps even pheromones, for communication between males or between the sexes, possibly related to courtship and insemination (Kutaygil, 1959; Nelson, 1964; Weitzman \& Fink, 1985).

Some characids also present a gill-derived gland, first described in the inseminating stevardiine Corynopoma riisei, and termed gill gland by Burns \& Weitzman (1996). In the study of Bushmann et al. (2002), gill glands were shown to be present in mature males of the inseminating species of twelve genera of the Stevardiinae (Acrobrycon, Argopleura, Chrysobrycon, Corynopoma, Gephyrocharax, Hysteronotus, Phenacobrycon, Planaltina, Pterobrycon, Scopaeocharax, Tyttocharax, and Xenurobrycon), but absent in the inseminating species of two stevardiine genera (Diapoma and Pseudocorynopoma) and in all inseminating species of the Glandulocaudinae [Ptychocharax was too immature to make a definitive statement]. This gland originates from the union and functional modification of the most anterior filaments of the first right and left gill arches. The entire lateral and medial surfaces of the gland are covered by stratified squamous epithelial tissue, resulting in individual chambers internally between adjacent gill filaments. A small opening remains near their ventral tips where the secretion is led to the exterior. Tall columnar secretory cells are found between adjacent secondary lamellae within the gland. The fact that they are present only in mature males suggests they may also release some type of chemical signal involved in reproduction and courtship and/or intermale aggression (Bushmann et al., 2002).

The presence of gill glands was also described for some characid genera belonging to a monophyletic subgroup of the Characidae designated clade A by Malabarba \& Weitzman (2003) and latter named Stevardiinae by Mirande $(2009,2010)$, that includes the Glandulocaudinae and the Stevardiinae sensu Weitzman et al. (2005). These gill glands were registered for Attonitus bounites (Weitzman et al., 2005: fig. 19a,b), A. irisae (Weitzman et al., 2005: fig. 19c), Bryconadenos tanaothoros (Weitzman et al., 2005: fig. 20), B. weitzmani (Menezes et al., 2009a: p.150), Bryconamericus exodon (Menezes et al., 2009a: p.49), Hemibrycon helleri (Bertaco \& Malabarba, 2010: p.743, fig. 7), H. huambonicus (Bertaco \& Malabarba, 2010: p.746, fig. 7), H. inambari (Bertaco \& Malabarba, 2010: p.748, fig. 7), $H$. jelskii (Bertaco \& Malabarba, 2010: p.749, fig. 7), Lepidocharax burnsi and L. diamantina (Ferreira et al., 2011: p.288), and Phallobrycon adenacanthus (Menezes et al., 2009a: fig. 5).
Among characids outside of Clade A or Stevardiinae sensu Mirande $(2009,2010)$, published data report the presence of gill glands in mature males of one species of the Aphyocharacinae, Aphyocharax anisitsi (Gonçalves et al., 2005: fig. 3); for six species of externally fertilized cheirodontines, Odontostilbe ecuadorensis (Bührnheim \& Malabarba, 2006: fig.16), O. fugitiva (Bührnheim \& Malabarba, 2006: fig.3), O. parecis (Bührnheim \& Malabarba, 2006: fig.16, p.92), O. pulchra (Bührnheim \& Malabarba, 2007: fig. 7), O. splendida (Bührnheim \& Malabarba, 2007: fig. 20), and O. pao (Bührnheim \& Malabarba, 2007: fig. $25)$; and one species of inseminating compsurins, Macropsobrycon uruguayanae (Azevedo et al., 2010: figs. 68; Jerep \& Malabarba, 2011: fig.7). In Aphyocharax anisitsi and Macropsobrycon uruguayanae, the development of the gill gland was found to be associated with the maturation of the testis (Gonçalves et al., 2005; Azevedo et al., 2010). The analysis of the gill gland of Macropsobrycon uruguayanae under transmission electronic microscopy found that the secondary lamellae within most of the gill gland are greatly reduced, with tall columnar cells between adjacent secondary lamellae containing abundant vesicles, suggesting secretory activity (Azevedo et al., 2010).

The presence of a gill-derived gland in males was tentatively used as a character in the characid phylogeny proposed by Mirande $(2009,2010)$. In this study, the presence or absence of this gland was found to be useful in phylogenetic studies. Although not described or illustrated, the gill gland was coded by Mirande (2010) as present in the characine Phenacogaster tegatus, in the aphyocharacines Aphyocharax anisitsi and $A$. dentatus, in the cheirodontines Axelrodia lindae, Cheirodon interruptus, Odontostilbe microcephala, O. paraguayensis, O. pequira, Prodontocharax melanotus, and Serrapinnus calliurus, in the stevardiines Acrobrycon tarijae, Attonitus ephimeros, Bryconamericus agna, B. exodon, B. cf. exodon, $B$. cf. iheringii, $B$. thomasi, and Cyanocharax alburnus, and in the incertae sedis characids Prionobrama paraguayensis and Aphyocharacidium bolivianum. The presence of the gill gland was interpreted as independently acquired, representing an autapomorphy for Phenacogaster tegatus and a synapomorphy for a clade containing the subfamilies Aphyocharacinae, Aphyoditeinae, Cheirodontinae, and Stevardiinae (sensu Mirande, 2010). Its loss was considered a synapomorphy for some internal clades of the Stevardiinae and for one species of the Aphyocharacinae (Mirande, 2010).

The purpose of the present study is to determine the distribution of gill glands in the Cheirodontinae, and to describe and compare their form and structure between inseminating and externally fertilizing species of the Cheirodontinae, as well as other members of the family Characidae.

\section{Material and Methods}

At least one species from thirteen cheirodontine genera were analyzed (including the compsurin "Odontostilbe" dialeptura that deserves a new generic assignment separately from Odontostilbe; Malabarba, 1998), totaling seventeen 
species, plus four species of other characid genera for comparative studies. Species of Amazonspinther, Pseudocheirodon, and Spintherobolus were not analyzed due to the lack of mature specimens. Gills of at least three mature males and two mature females of each species were selected, when available. Histological sections of the gonads were made to confirm degree of sexual maturity. Most specimens were obtained from museum collections; therefore the whole fish had been fixed in formalin and stored in $70 \%$ ethanol. The first and second gill arches of both right and left sides were removed, the right arches were used for light microscopy and the left arches were used for Scanning Electron Microscopy (SEM). Transmission Electron Microscopy (TEM) analysis were made on the gill arch fixed from freshly collected specimens.

For light microscopy, the first and second right gill arches were decalcified in 10\% ethylenediamine tetracetic acid (EDTA) for five days, dehydrated in an ethanol series, infiltrated and embedded in glycol methacrylate. Sagittal sections of the gills were cut at 3 to $5 \mu \mathrm{m}$ and stained with hematoxylin and eosin (HE), toluidine blue, or periodic acid/Schiff reagent (PAS).

For SEM, the first and second left gill arches were cleaned with ultrasound equipment for 6 minutes, dehydrated in a graded ethanol series, critical point dried in liquid $\mathrm{CO}_{2}$, glued onto stubs with carbon double-stick tape and sputter-coated with carbon and gold. Images were visualized and photographed in a Jeol 6060 scanning electron microscopy at the Universidade Federal do Rio Grande do Sul, Brazil or in a Philips XL 30 scanning electron microscope at the Pontifícia Universidade Católica do Rio Grande do Sul, Brazil.

For TEM, fishes were sacrificed in the field by a cut through the spinal cord. The first left gill arch of five mature males of Compsura heterura were fixed in 2.5\% glutaraldehyde and 2\% paraformaldehyde in $0.1 \mathrm{M}$ phosphate buffer, $\mathrm{pH} 7.4$ and kept under refrigeration until the start of sample processing. The gills were post-fixed in $1 \%$ osmium tetroxide in phosphate buffer, dehydrated in an acetone series, infiltrated and embedded in Araldite-Epon (Embed-812). Ultrathin sections were stained with a saturated solution of uranyl acetate at $50 \%$ alcohol and lead citrate. The sections were viewed in a Philips CM100 transmission electron microscope at the Universidade Estadual Paulista, Câmpus Botucatu, Brazil.

Examined specimens belong to ANSP - Academy of Natural Sciences, Philadelphia, USA; CAS - California Academy of Sciences, San Francisco, USA; MCP - Museu de Ciências e Tecnologia, Porto Alegre, Brazil; MCNG - Museo de Ciencias Naturales, Guanare, Venezuela; MNRJ - Museu Nacional, Rio de Janeiro, Brazil; NRM - Swedish Museum of Natural History, Stockholm, Sweden; UFRGS - Universidade Federal do Rio Grande do Sul, Porto Alegre, Brazil; and USNM - National Museum of Natural History, Washington D.C., USA.

Material examined. Inseminating species. Acinocheirodon melanogramma, MCP 19142, 3 males 32.2-35.0 mm SL, 2 females 33.6-38.3 mm SL. Compsura heterura, UFRGS 8978, 3 males 28.1$29.7 \mathrm{~mm}$ SL, 2 females 28.1-28.7 mm SL. Kolpotocheirodon theloura, MNRJ 18081, 6 males 25.0-26.3 mm SL, 2 females 24.1-24.8 mm
SL; UFRGS 8792, 3 males 32.8-35.3 mm SL, 2 females 29.5-38.8 mm SL. "Odontostilbe" dialeptura, USNM 209511, 4 males 32.2$35.1 \mathrm{~mm}$ SL, 2 females 32.5-32.6 mm SL. Saccoderma hastata, ANSP 139487, 8 males 29.1-31.3 mm SL, 3 females 29.0-29.5 mm SL; CAS 70918, 2 males 25.1-26.3 mm SL, female 26.1 mm SL; MCP 16169, 2 males 24.4-24.6 mm SL, female $26.1 \mathrm{~mm}$ SL. Externally fertilizing species. Aphyocheirodon hemigrammus, NRM 17307, male 29.0 mm SL. Cheirodon ibicuhiensis, UFRGS 9042, 3 males 31.5-34.1 mm SL; UFRGS 9041, 2 females 38.5-43.1 mm SL. Cheirodontops geayi, MCNG 14197, 5 males 27.7-30.1 mm SL, 2 females 29.9-31.3 mm SL. Heterocheirodon jacuiensis, MCP 14283, 3 males 40.0-42.1 $\mathrm{mm}$ SL, 3 females 38.9-43.0 mm SL. Heterocheirodon yatai, MCP 14283, 4 males 31,6-34.8 mm SL, 3 females 33.7-35.3 mm SL. Nanocheirodon insignis, USNM 121518, 4 males 20.3-25.6 mm SL, female $21.1 \mathrm{~mm}$ SL. Odontostilbe fugitiva, MCP 35775, 5 males 33.8-36.0 mm SL. Odontostilbe pequira, UFRGS 8980, 3 males 36.7$38.7 \mathrm{~mm}$ SL, 2 females 40.9-41.1 mm SL. Prodontocharax melanotus, USNM 326941, male $38.1 \mathrm{~mm}$ SL. Serrapinnus heterodon, UFRGS 8793, 6 males 27.8-30.8 mm SL, 2 females 28.7-29.0 mm SL. Serrapinnus piaba, UFRGS 8794, 3 males 28.4-28.5 mm SL, 2 females 29.0-31.2 mm SL).

\section{Results}

Gill glands were found in all analyzed mature males of the Cheirodontinae (Figs. 1 and 2) and were always absent in females. They were always located on the anteriormost portion of the lower branch of the first gill arch, extending posteriorly through a variable number of gill filaments. The gill gland was also present on the second gill arch of Compsura heterura and Saccoderma hastata, but occupying just half the length of the filaments of the second gill arch and extending through a smaller number of gill filaments than those from the first gill arch.

The development of gill glands begins with the multiplication of epithelial cells that will form a lateral cover over the anteriormost portion of the lower branch of the first gill arch. This cover will continue to extend over successively more posterior filaments. When gill glands do not occupy the entire gill arch, unmodified filaments are located immediately posterior to the gill glands (Figs. 1-4). The gill glands are covered laterally by stratified squamous epithelial tissue and are divided internally by the gill filaments thus forming separate elongate chambers. No connections were seen between adjacent chambers (Figs. 3 and 4). On some sections, the skeletal muscle associated with the hyaline cartilage of the gill filaments was visible (Fig. 3f, i). Secretory cells occupy the areas between adjacent secondary lamellae within the gill glands (Figs. 3 and 4). The secretions produced by the glands exit through distal openings of the gland chambers, where the adjacent filaments are not fused.

The pseudostratified epithelial tissue located between the adjacent secondary lamellae consists of tall columnar cells. With TEM, abundant electron-dense vesicles are visible throughout the cytoplasm of most of the cell (Fig. 5). The nucleus, endoplasmatic reticulum and Golgi complex are located in the basal region of the cells.

In spite of the basic gill gland structure being similar among species, some differences were observed in gland size (number 
of filaments) and in the degree of gill modification. Gill glands are larger in inseminating cheirodontines (Figs. 1 and 3) (Compsura heterura has 15 filaments on the first gill arch comprising a gill gland; Kolpotocheirodon theloura, 18 filaments; Macropsobrycon uruguayanae, 25 filaments; "Odontostilbe" dialeptura, 28 filaments; Saccoderma hastata,
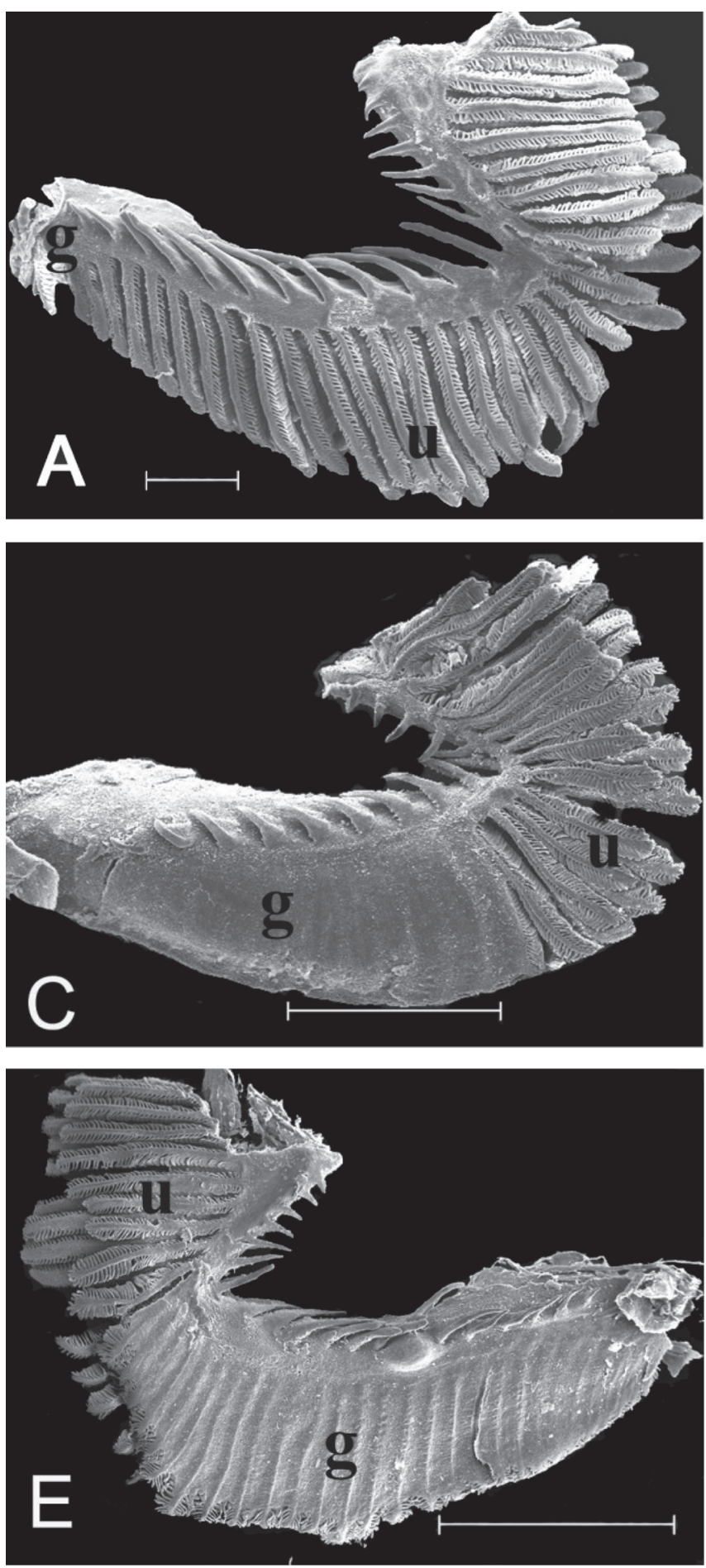

28 filaments); externally fertilizing species (Figs. 2 and 4 ) have fewer filaments comprising the glands (Aphyocheirodon hemigrammus has 9 filaments; Cheirodon ibicuhiensis, 9 filaments; Cheirodontops geayi, 10 filaments; Heterocheirodon jacuiensis, 7 filaments; H. yatai, 7 filaments; Nanocheirodon insignis, 7 filaments; Odontostilbe fugitiva, 6 filaments; $O$.
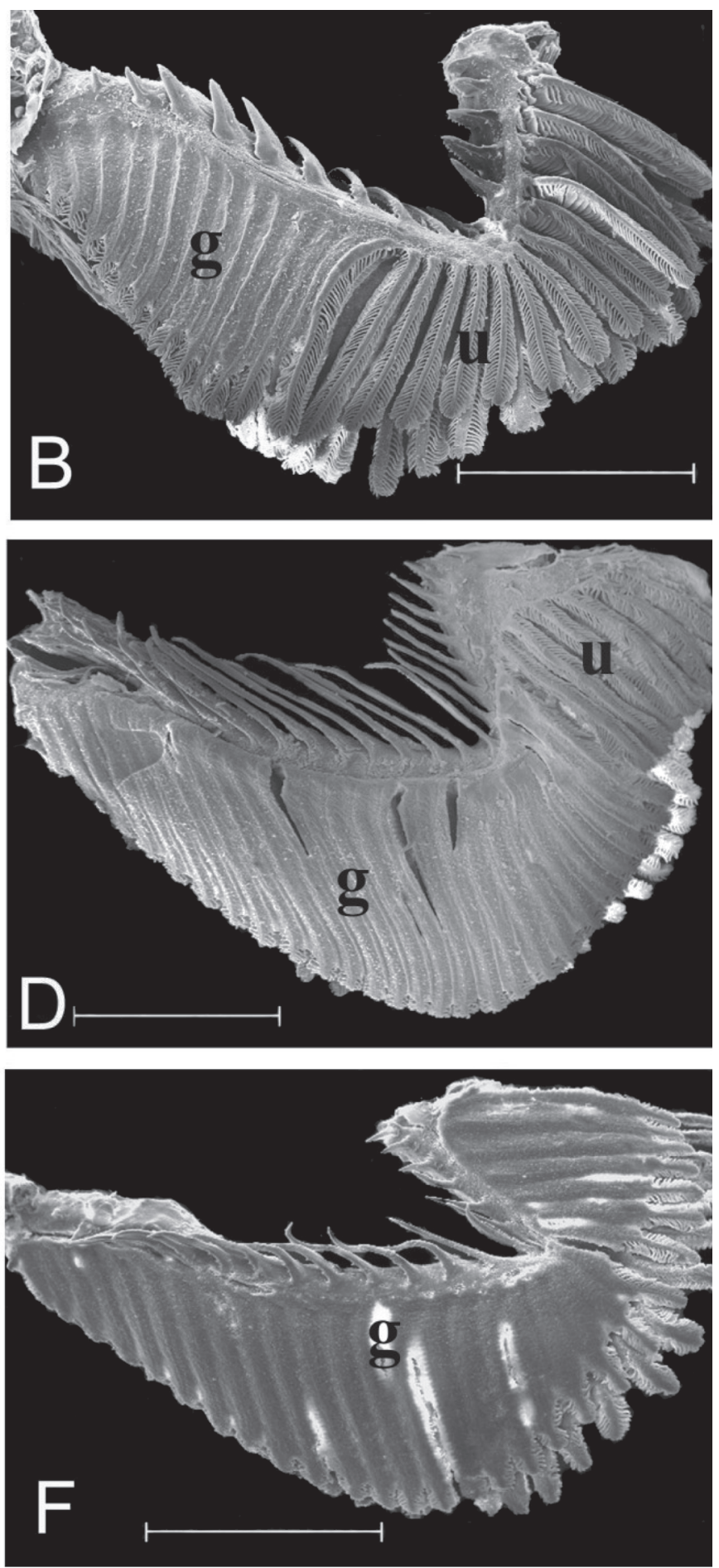

Fig. 1. Scanning electron micrographs (SEMs) of first left (A-D, F) and right (E) gill arches of male inseminating cheirodontines, (A) Acinocheirodon melanogramma, (B) Compsura heterura, (C) Kolpotocheirodon theloura, (D) Macropsobrycon uruguayanae, (E) Odontostilbe dialeptura, and (F) Saccoderma hastata. Gill glands (g), unmodified gill filaments (u). Scale bars: 1 mm. 

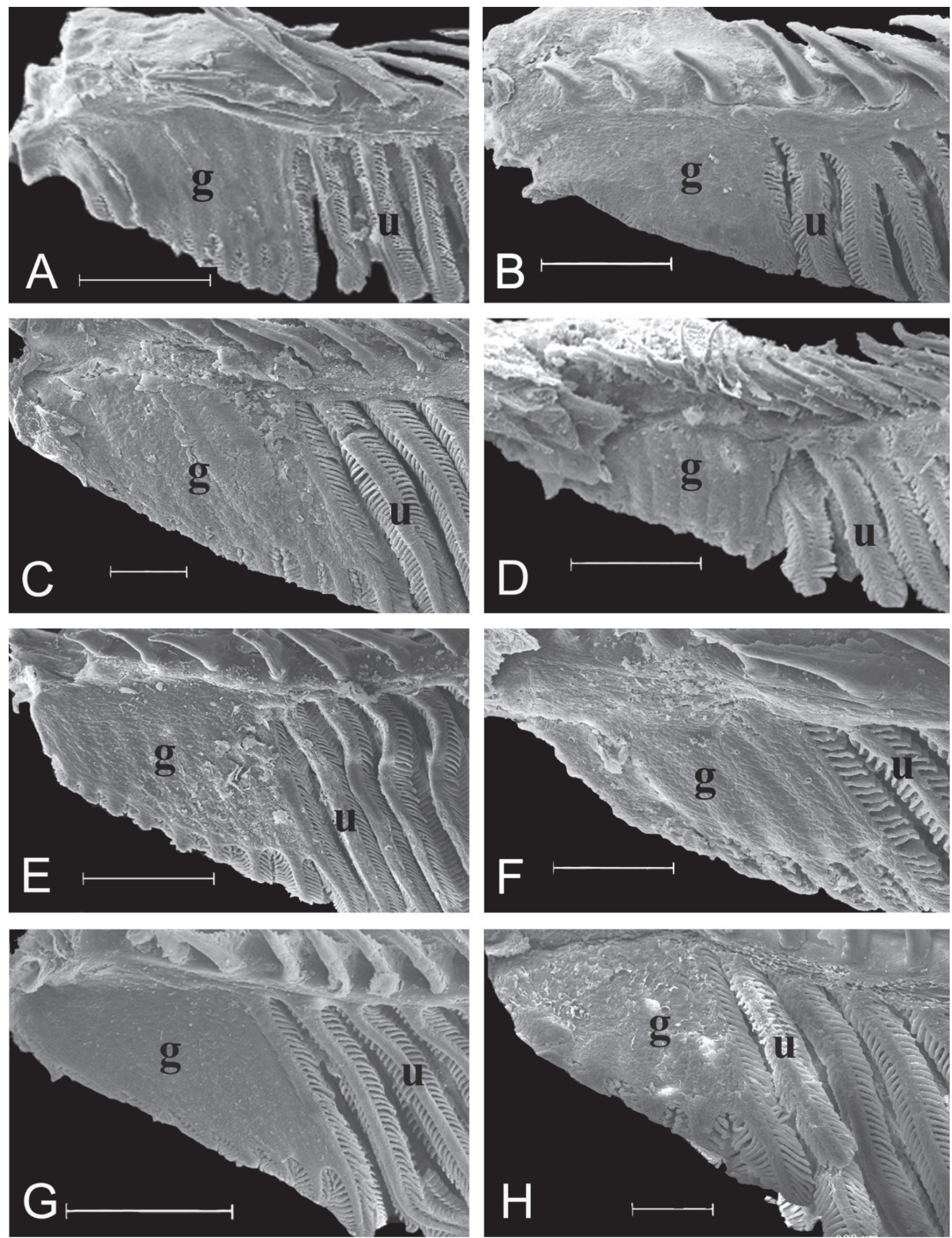

Fig. 2. Scanning electron micrographs (SEMs) of first left gill arch of male externally fertilizing cheirodontines, (A) Aphyocheirodon hemigrammus, (B) Cheirodon ibicuhiensis, (C) Cheirodontops geayi, (D) Heterocheirodon yatai, (E) Odontostilbe fugitiva, (F) Nanocheirodon insignis, (G) Prodontocharax melanotus, and (H) Serrapinnus heterodon. Gill glands (g), unmodified gill filaments (u). Scale bars: $200 \mu \mathrm{m}$ (A, B, C, D, H), $500 \mu \mathrm{m}$ (E, G). 

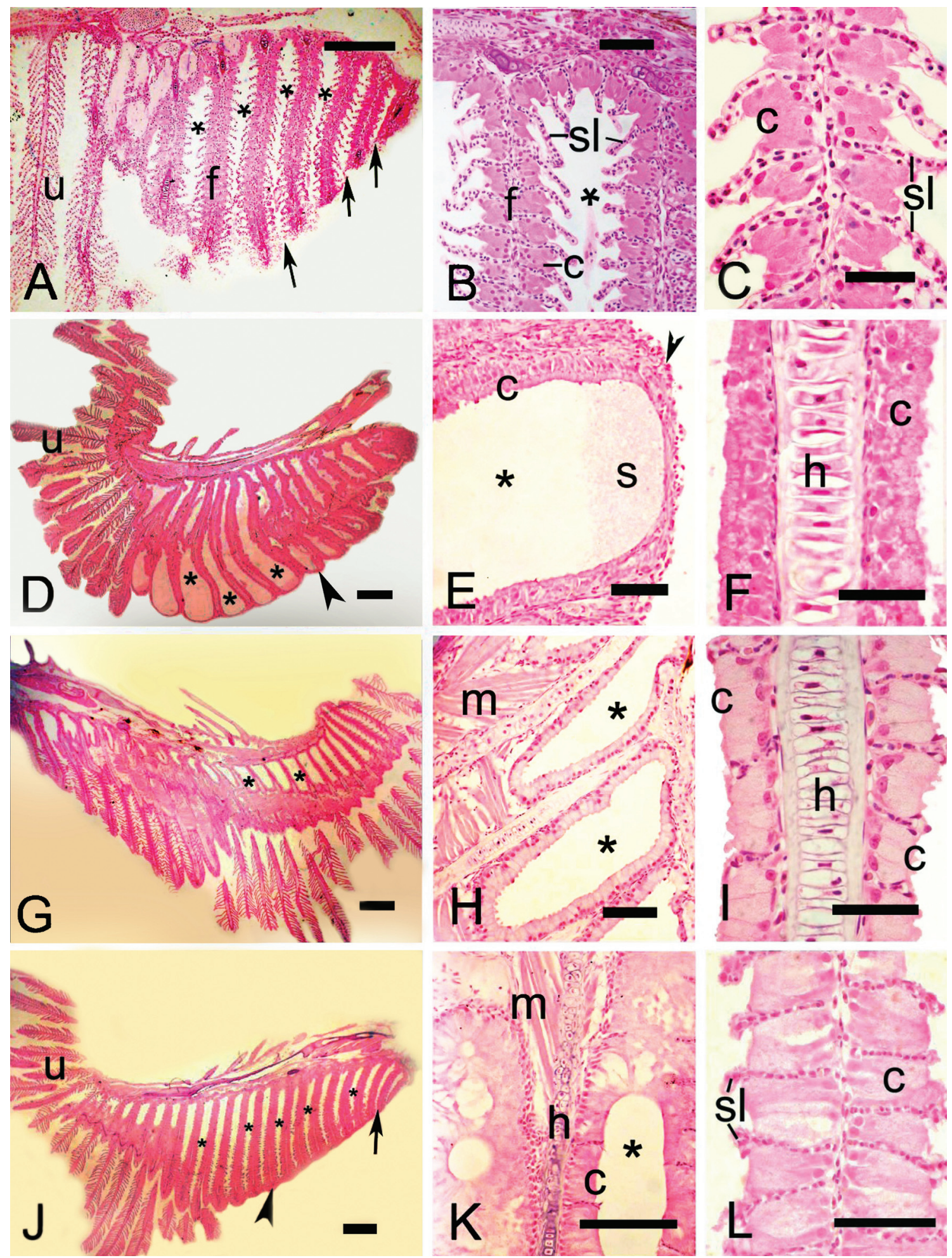

Fig. 3. Sagittal histological sections through first gill arches of males of the inseminating cheirodontines, (A, B, C) Acinocheirodon melanogramma, $(\mathbf{D}, \mathbf{E}, \mathbf{F})$ Kolpotocheirodon theloura, $(\mathbf{G}, \mathbf{H}, \mathbf{I})$ Macropsobrycon uruguayanae, and $(\mathbf{J}, \mathbf{K}, \mathbf{L})$ Saccoderma hastata . Asterisk = lumen of gill gland chamber; $\mathrm{c}=$ columnar cells; $\mathrm{f}=$ gill filaments; $\mathrm{s}$ = gill secondary lamellae; $\mathrm{s}=$ secretion; $\mathrm{u}=$ unmodified gill filaments; arrow $=$ ventral opening of the chamber; arrowhead $=$ gill gland cover; $\mathrm{m}=$ skeletal muscle; $\mathrm{h}=$ hyaline cartilage of gill filaments. Scale bars: $150 \mu \mathrm{m}$ (A, D, G, J), $50 \mu \mathrm{m}$ (B, E, H, K), $25 \mu \mathrm{m}(\mathrm{C}, \mathrm{F}, \mathrm{I}, \mathrm{L})$. 

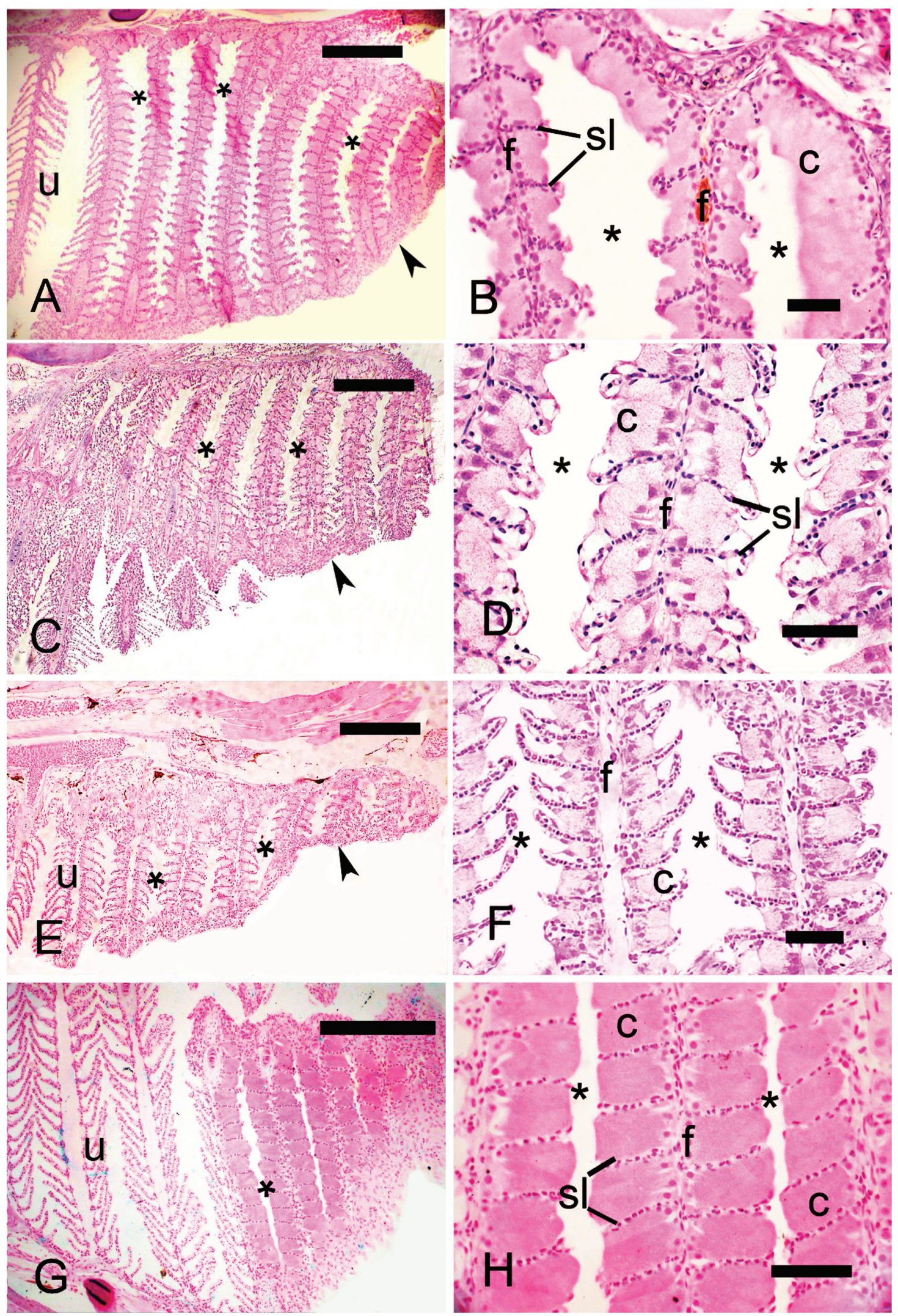

Fig. 4. Sagittal histological sections through first gill arches of males of the externally fertilizing cheirodontines, (A, B) Aphyocheirodon hemigrammus, (C, D) Heterocheirodon yatai, (E, F) Prodontocharax melanotus, (G, H) Serrapinnus heterodon. Asterisk = lumen of gill gland chamber; $\mathrm{f}=$ gill filaments; $\mathrm{s}$ = gill secondary lamellae; $\mathrm{u}=$ unmodified gill filaments; arrowhead = gill gland cover; arrow $=$ gill gland cover. Scale bars: $150 \mu \mathrm{m}(\mathrm{A}, \mathrm{C}, \mathrm{E}, \mathrm{G}), 25 \mu \mathrm{m}(\mathrm{B}, \mathrm{D}, \mathrm{F}, \mathrm{H})$. 
pequira, 10 filaments, Prodontocharax melanotus, 4 filaments; Serrapinnus heterodon, 8 filaments; S. piaba, 7 filaments). The only exception is the compsurin Acinocheirodon

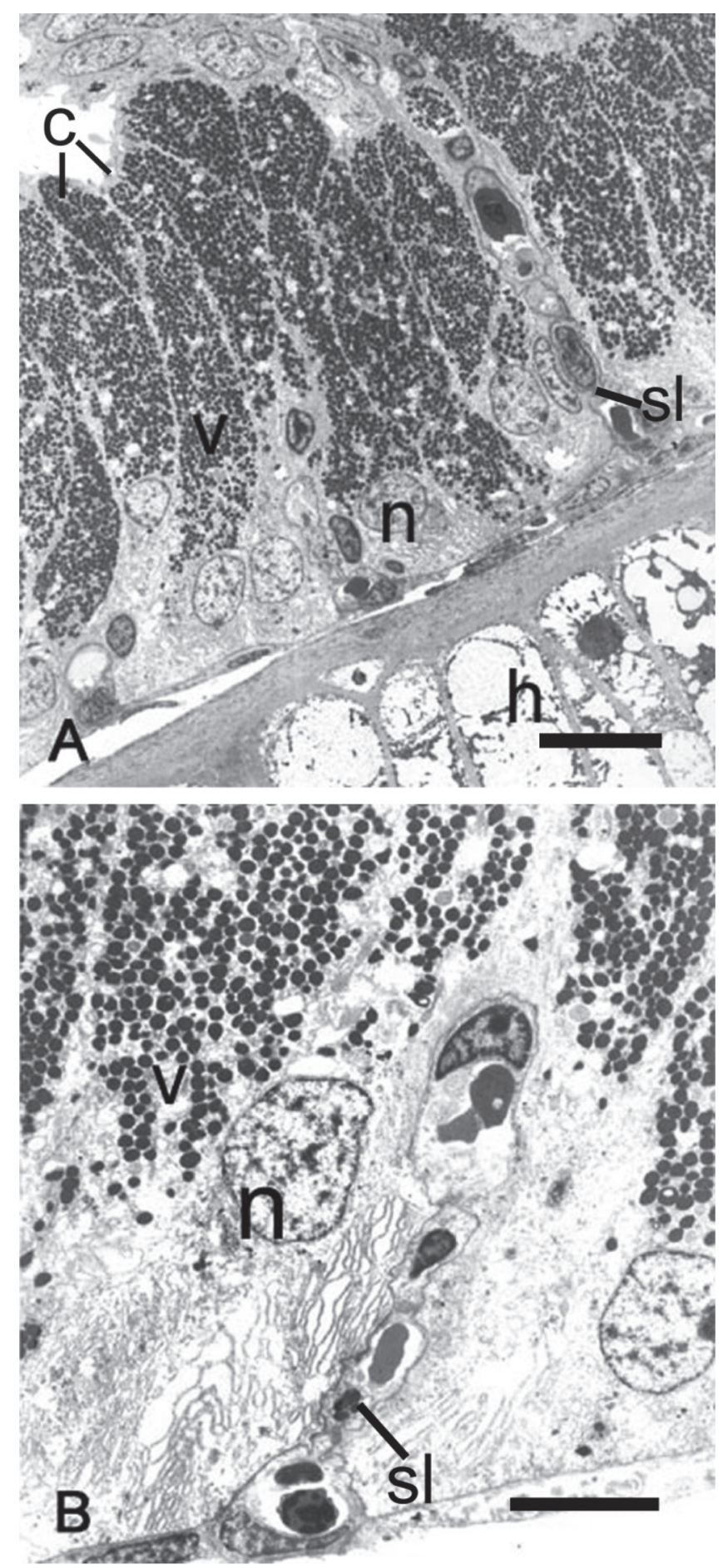

Fig. 5. Transmission electron micrographs (TEMs) of sagittal sections through gill glands of Compsura heterura. Tall columnar cells (c) are found between adjacent secondary lamellae (sl). Abundant electron-dense vesicles (v) occupy almost the whole cell; nuclei (n) are near the base of cells. $h$, hyaline cartilage. Scale bars: $8 \mu \mathrm{m}(\mathrm{A}), 5 \mu \mathrm{m}$ (B). melanogramma (Figs. 1A, 3A) whose glands were formed by fewer gill filaments (8-10 filaments) than other inseminating species. In Compsura heterura and Saccoderma hastata gill glands were also present on the second gill arch, comprising 5 and 4-13 filaments, respectively (Fig. 6).

Unlike the other examined cheirodontine species, the chambers of the gill glands of Kolpotocheirodon theloura do not appear to open distally (Fig. 6B) but were fused at their distal tips instead. This species has a turgid gill gland when viewed externally, and internally it is possible to observe large chambers with noncellular stained material within (Fig. 3E).

The secondary gill lamellae within the gill gland chambers of Aphyocheirodon hemigrammus, Compsura heterura, Kolpotocheirodon theloura, Macropsobrycon uruguayanae, and Saccoderma hastata were greatly shortened or even absent in some regions with only the columnar secretory cells remaining (Fig. 3F).

\section{Discussion}

\section{Relationships among characids sharing a gill gland.}

Gill glands of all characid species in which this organ has been described possess the same structure. They are formed externally by the growth of stratified squamous epithelial tissue over and around the most anterior gill filaments of the lower branch of the first gill arch thus forming chambers between adjacent gill filaments that generally open into the main gill cavity ventrally. In addition, gill secondary lamellae are generally reduced in length or completely atrophied, with pseudostratified columnar epithelial cells containing secretory vesicles located between adjacent secondary lamellae (Burns \& Weitzman, 1996; Bushmann et al., 2002; Weitzman et al., 2005; Azevedo et al., 2010; this paper). This similar complex structural pattern of the gill gland supports a primary hypothesis of homology and unique origin among the species of the Characidae. So far, this complex structure has been described for species of Clade A (sensu Malabarba \& Weitzman, 2003) or Stevardiinae (sensu Mirande, 2010) both including the Glandulocaudinae and Stevardiinae (sensu Weitzman et al., 2005); and for species of the Aphyocharacinae, Characinae, and Cheirodontinae.

There are three recent phylogenies proposed for characid fishes, all recognizing a large and monophyletic internal characid clade composed of those species lacking a supraorbital bone, as previously proposed by Malabarba \& Weitzman (2003), but with alternative views of the relationships among the components of this clade (Fig. 7). One of the main differences among the three disputing hypotheses is related to the position of the subfamily Characinae, placed in a more basal position among the characids lacking a supraorbital bone in Mirande's hypothesis, which requires the gill gland to have appeared independently twice in the Characinae (Phenacogaster tegatus) and in a clade formed by Aphyocharacinae, Aphyoditeinae, Cheirodontinae, and Stevardiinae (sensu Mirande, 2010). The alternative hypotheses of Javonillo et al. (2010) and Oliveira et al. (2011) suggests a single appearance of the gill gland in the common ancestor of the group formed by their Clade A 

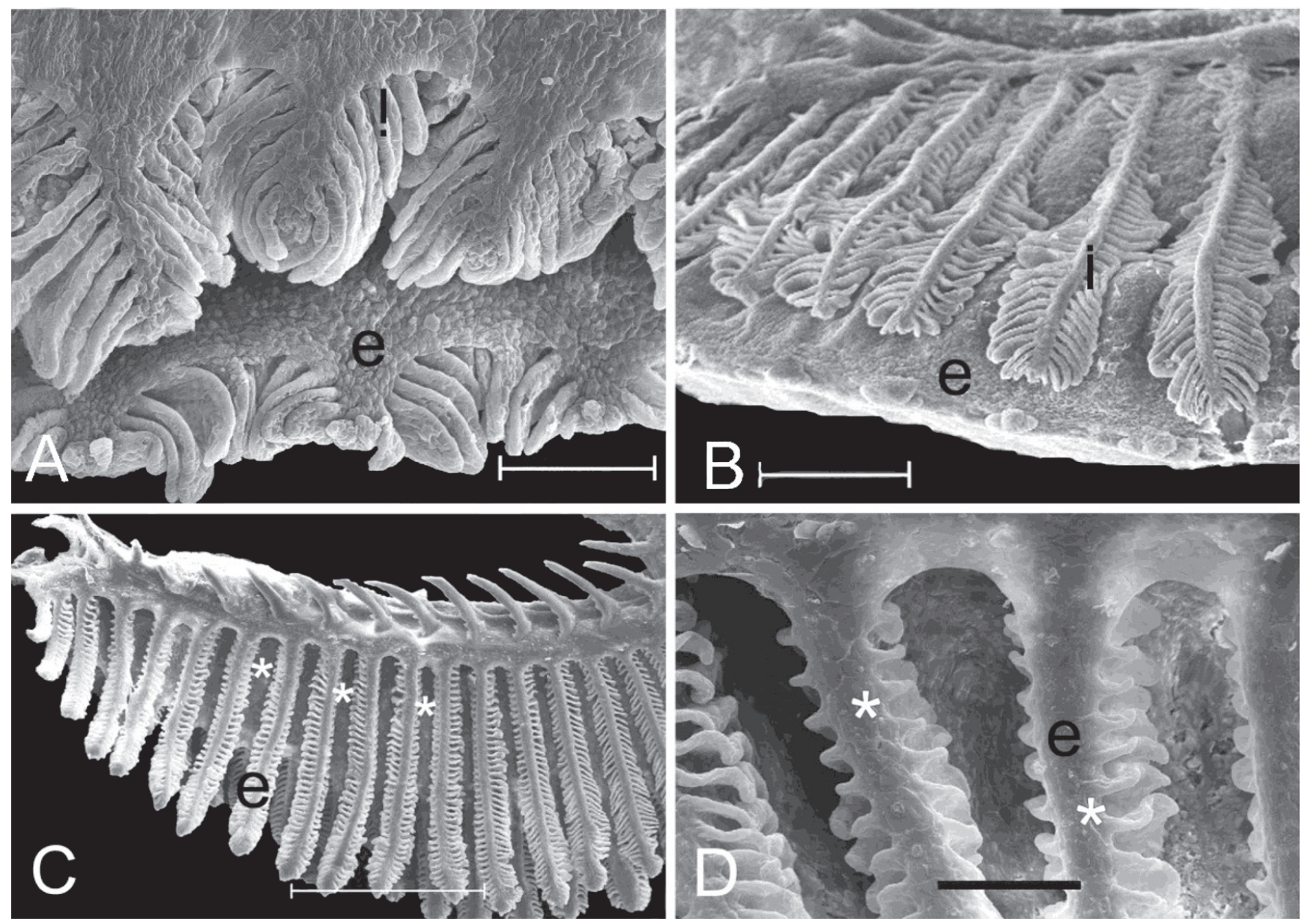

Fig. 6. Scanning electron micrograph of gill arches. A) Lateral view of first gill arch of Compsura heterura, with gill glands occupying both hemibranchs, both with the same extension. Scale bar: $100 \mu \mathrm{m}$. B) Medial view of first gill arch of Kolpotocheirodon theloura, with gland of external hemibranch embracing internal filaments. Scale bar: $200 \mu \mathrm{m}$. C) Lateral view of second gill arch of Saccoderma hastata. In Saccoderma hastata, the glands may be in the external (e) or internal hemibranch (i and asterisks) of the second gill arches. Scale bar: $500 \mu \mathrm{m}$. D) Detail of micrograph C. Scale bar: $100 \mu \mathrm{m}$.

(including Glandulocaudinae and Stevardiinae sensu Weitzman et al., 2005 and some incertae sedis genera) plus Clade B (containing the Aphyocharacinae, Characinae, Cheirodontinae, Tetragonopterinae (sensu stricto), Exodon and Roeboexodon)). The last two hypotheses support the single appearance of the gill gland which is proposed herein as a morphological synapomorphy supporting the monophyly of the group formed by Clade A and Clade B of Javonillo et al. (2010) and Oliveira et al. (2011).

It is important to note that although the gill gland seems to have appeared in a common ancestor of those clades discussed above, this structure is absent in the phenotype of several of their members, as for example in two of the fifteen genera of the Stevardiinae (Bushmann et al., 2002). Also, detection of the gill gland depends on the examination of mature or late maturing males, otherwise they are not developed (Gonçalves et al., 2005, Azevedo et al., 2010). The alternative expression of this character among taxa may have diminished its weight in the implied weighting analysis of Mirande (2010) reducing the explanatory power of this character for characid phylogeny.
Although Mirande (2010) coded the presence of a gill gland in Phenacogaster tegatus, no description of the gland was provided. JRB had available histological preparations of the gill gland of a mature male of $P$. franciscoensis $(37.4 \mathrm{~mm} \mathrm{SL}$, USNM 345675) and can report that the location, anatomy and histology of the Phenacogaster gill gland is essentially identical to that of other species that possess them.

Among taxa of Clade A, gill glands were found to be present on histological preparations by JRB (unpublished) in mature inseminating males of Creagrutus melasma and Monotocheirodon species, and in mature males of externally fertilizing species of the genera Bryconamericus, Caiapobrycon, Creagrutus, Cyanocharax, Hemibrycon, Hypobrycon, Knodus, Piabina, Rhinobrycon, and Rhinopetitia.

The absence of a gill gland has been registered for some taxa belonging to Clade C of Javonillo et al. (2010) and Oliveira et al. (2011), further supporting this hypothesis: Astyanax utiariti by Bertaco \& Garutti (2007), Astyanax jordanensis by Alcaraz et al. (2009), Astyanax goyanensis and Astyanax 

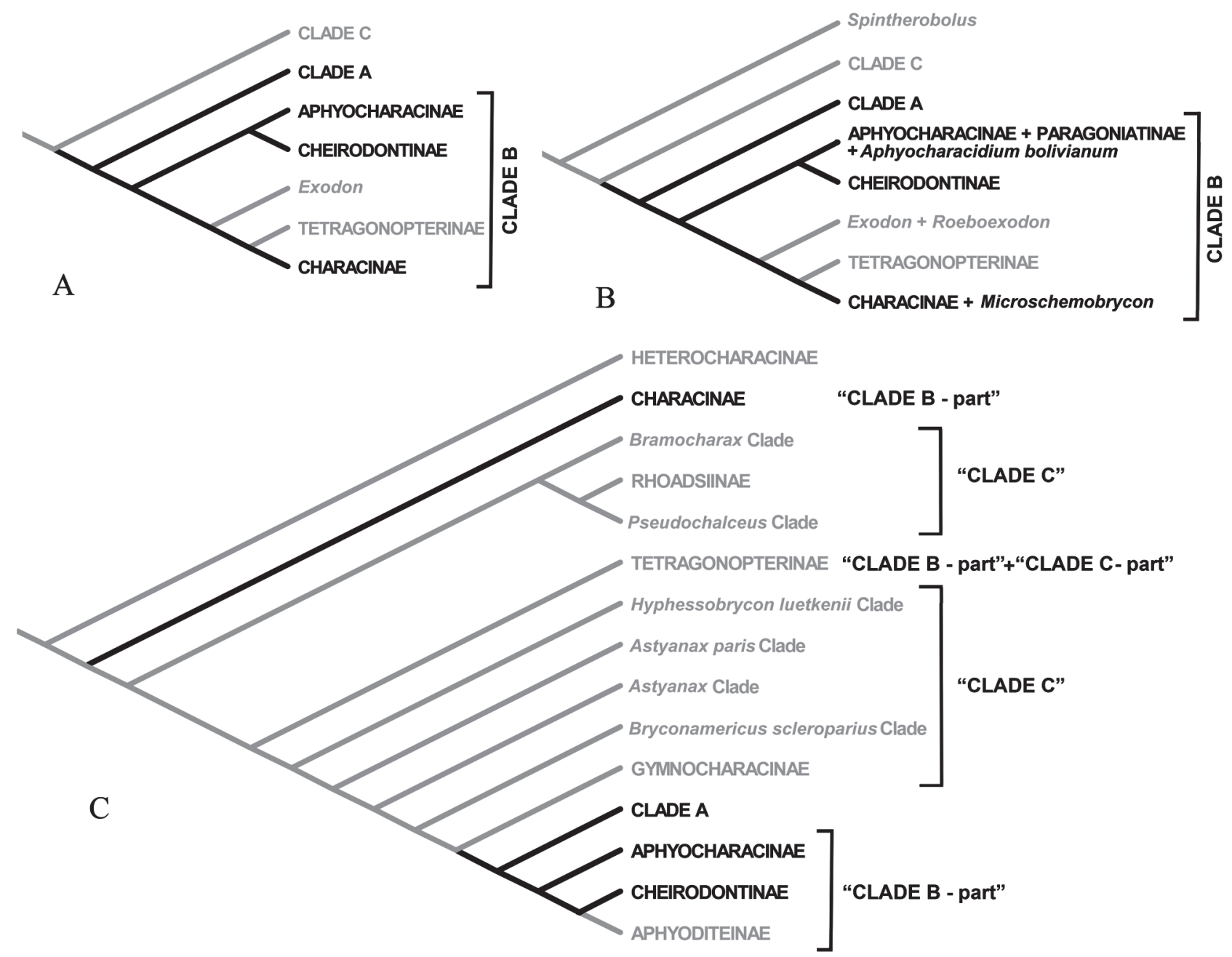

Fig. 7. Phylogenetic relationships among characid fishes lacking the supraorbital bone, as hypothesized by A) Javonillo et al. (2010), B) Oliveira et al. (2011), and C) Mirande (2010). Black lines represent lineages containing species documented to have gill glands. Gray lines represent lineages without records of gill glands. Clades A, B, and C as defined by Javonillo et al. (2010) and Oliveira et al. (2011) are marked in Mirande's (2010) hypothesis for comparison. Tetragonopterinae sensu Javonillo et al. (2010) and Oliveira et al. (2011) includes a single genus, Tetragonopterus. Tetragonopterinae sensu Mirande (2010) includes Tetragonopterus plus 18 genera assigned to Clade C by Javonillo et al. (2010) and Oliveira et al. (2011).

courensis by Bertaco et al. (2010), Astyanax obscurus and A. laticeps by Bertaco \& Lucena (2010), Ectrepopterus uruguayensis by Malabarba et al. (2012) [see Thomaz et al., 2010 for the relationships of Ectrepopterus uruguayensis, formerly as Hyphessobrycon uruguayensis, with clade $\mathrm{C}$ taxa], Hasemania kalunga by Bertaco \& Carvalho (2010), Hemigrammus tocantinsi by Carvalho et al. (2010), Hemigrammus ora by Jerep et al. (2011), Hyphessobrycon melanostichos and Hyphessobrycon notidanos by Carvalho $\&$ Bertaco (2006), Hyphessobrycon vinaceus by Bertaco et al. (2007), and Oligosarcus itau by Mirande et al. (2011).

Putative function of the gill gland in inseminating characids.

It is evident that both externally fertilizing and inseminating characids may have gill glands, therefore, there is no relationship between the presence of a gill gland and insemination. Comparing the gill glands of inseminating and externally fertilizing species of the Cheirodontinae, however, we clearly find a difference in their degree of development. The gill gland tends to be smaller in externally fertilizing species of the Cheirodontinae, being composed of a maximum of 10 gill filaments. In the inseminating species of the tribe Compsurini, such as in Macropsobrycon uruguayanae, "Odontostilbe" dialeptura and Saccoderma hastata, the gill gland develops from a larger number of gill filaments, and in some cases occupies nearly the entire gill arch, comprising up to 28 gill filaments (Fig. 1F).

Gill glands of Kolpotocheirodon theloura appeared turgid upon dissection, and histological examination confirmed the presence of noncellular material within the gill gland chambers. The state of expansion and secretion of gill glands can vary greatly even within a given species (Burns \& Weitzman, 1996) 
with this possibly being related to cyclic changes in testis maturation. Immature male specimens do not have gill glands, while males undergoing the early stages of testis maturation have glands in intermediate stages of development, and mature males have well-developed glands (Burns and Weitzman, 1996; Gonçalves et al., 2005; Azevedo et al., 2010). In one mature male specimen of Corynopoma riisei, the gill glands had regions that were more expanded and turgid containing a light yellow viscous secretion upon dissection (Burns \& Weitzman, 1996).

The union of the gill filaments, the covering with a stratified squamous epithelium, and the reduction or loss of secondary lamellae within the gland all contribute to decrease or impede gaseous exchanges within the gill glands themselves (Burns \& Weitzman, 1996), making respiration more costly. The presence of the gill gland in mature males and absence in females suggest that the secretion produced may serve as some type of chemical signal, perhaps to attract females during courtship (Burns \& Weitzman, 1996; Bushmann et al., 2002) or intermale aggression (Bushmann et al., 2002). The comparatively larger size of the gill gland in inseminating versus externally fertilized species of the Cheirodontinae suggests that these secretions may be particularly important for the reproductive success of inseminating cheirodontines. Gill glands of most species of Compsurini also reach larger sizes than those of the inseminating Stevardiinae, that also show varying degrees of gill gland sizes (Bushmann et al., 2002), ranging from 4 to 13 gill filaments.

A recent preliminary study by Shrestha et al. (2010) used the technique of laser ablation electrospray ionization (LAESI) combined with mass spectrometry (MS) to study potentially unique compounds in gill glands. With this technique, the tissue to be analyzed is vaporized with a laser, and the compounds released immediately detected and analyzed by a mass spectrometer. Tissues studied included male gill glands, adjacent unmodified gill areas in the same males, and gill areas from females in the same region that gill glands are located in males, from mature specimens of the bloodfin tetra, Aphyocharax anisitsi, purchased from a local pet shop. This technique identified a protein of molecular weight 11,386 Daltons that was found only in the gill gland tissue; it was absent from adjacent male gill areas and from female gill tissue. This unique gill gland protein could potentially be the putative chemical signal proposed above, or possibly serve as an enzyme for the production of such a chemical signal. Further studies involving conventional proteomics, chemical isolation and behavioral experiments will be required to confirm this.

\section{Acknowledgements}

We thank the technicians of the Centro de Microscopia Eletrônica of the Universidade Federal do Rio Grande do Sul, Porto Alegre, Brazil, Pontifícia Universidade Católica do Rio Grande do Sul, Porto Alegre, Brazil, and Universidade Estadual Paulista, Botucatu, Brazil. George Mattox provided valuable comments to this manuscript. This work was supported by Conselho Nacional de Desenvolvimento Científico e Tecnológico (CNPq).

\section{Literature Cited}

Alcaraz, H. S. V., C. Pavanelli \& V.A. Bertaco. 2009. Astyanax jordanensis (Ostariophysi: Characidae), a new species from the rio Iguaçu basin, Paraná, Brazil. Neotropical Ichthyology, 7: 185-190.

Azevedo, M. A., L. R. Malabarba \& J. R. Burns. 2010. Reproductive biology and development of gill glands in the inseminating characid, Macropsobrycon uruguayanae Eigenmann, 1915 (Cheirodontinae: Compsurini). Neotropical Ichthyology, 8: 87-96.

Bertaco, V. A. \& F. R. Carvalho. 2010. New species of Hasemania (Characiformes: Characidae) from Central Brazil, with comments on the endemism of upper rio Tocantins basin, Goiás State. Neotropical Ichthyology, 8: 27-32.

Bertaco, V. A. \& V. Garutti. 2007. New Astyanax from the upper rio Tapajós drainage, Central Brazil (Characiformes: Characidae). Neotropical Ichthyology, 5: 25-30.

Bertaco, V. A. \& C. A. S. Lucena. 2010. Redescription of Astyanax obscurus (Hensel, 1870) and A. laticeps (Cope, 1894) (Teleostei: Characidae): two valid freshwater species originally described from rivers of Southern Brazil. Neotropical Ichthyology, 8: 7-20.

Bertaco, V. A. \& L. R. Malabarba. 2010. A review of the CisAndean species of Hemibrycon Günther (Teleostei: Characiformes: Characidae: Stevardiinae), with description of two new species. Neotropical Ichthyology, 8: 737-770.

Bertaco, V. A., L. R. Malabarba \& J. A. Dergam. 2007. New Hyphessobrycon from the upper rio Pardo drainage in eastern Brazil (Teleostei: Characiformes: Characidae). Neotropical Ichthyology, 5: 245-249.

Bührnheim, C. M., T. P. Carvalho, L. R. Malabarba \& S. H. Weitzman. 2008. A new genus and species of characid fish from the Amazon basin: the recognition of a relictual lineage of characid fishes (Ostariophysi: Cheirodontinae: Cheirodontini). Neotropical Ichthyology, 6: 663-678.

Bührnheim, C. M. \& L. R. Malabarba. 2006. Redescription of the type species of Odontostilbe Cope, 1870 (Teleostei: Characidae: Cheirodontinae), and description of three new species from the Amazon basin. Neotropical Ichthyology, 4:167-196.

Bührnheim, C. M. \& L. R. Malabarba. 2007. Redescription of Odontostilbe pulchra (Gill, 1858) (Teleostei: Characidae: Cheirodontinae), and description of two new species from the río Orinoco basin. Neotropical Ichthyology, 5: 1-20.

Burns, J. R. \& S. H. Weitzman. 1996. Novel gill-derived gland in the male swordtail characin, Corynopoma riisei (Teleostei: Characidae: Glandulocaudinae). Copeia, 1996: 627-633.

Burns, J. R. \& S. H. Weitzman. 2005. Insemination in ostariophysan fishes. Pp. 107-134. In: Uribe, M. C. \& H. J. Grier (eds.). Viviparous Fishes. Homestead, FL: New Life Publications.

Burns, J. R., S. H. Weitzman, K. R. Lange \& L. R. Malabarba. 1998. Sperm ultrastructure in characid fishes (Teleostei: Ostariophysi). Pp. 235-244. In: L. R. Malabarba, R. E. Reis, R. P. Vari, Z. M. S. Lucena \& C. A. S. Lucena (Eds.). Phylogeny and Classification of Neotropical Fishes. Porto Alegre, Brazil: EDIPUCRS.

Burns, J. R., S. H. Weitzman \& L. R. Malabarba. 1997. Insemination in eight species of cheirodontine fishes (Teleostei: Characidae: Cheirodontinae). Copeia, 1997: 433-438.

Bushmann, P. J., J. R. Burns \& S. H. Weitzman. 2002. Gill-derived glands in glandulocaudine fishes (Teleostei: Characidae: Glandulocaudinae). Journal of Morphology, 253: 187-195.

Carvalho, T. P. \& V. A. Bertaco. 2006. Two new species of Hyphessobrycon (Teleostei: Characidae) from upper rio Tapajós basin on Chapada dos Parecis, Central Brazil. Neotropical Ichthyology, 4: 301-308. 
Carvalho, F. R., V. A. Bertaco \& F. C. Jerep. 2010. Hemigrammus tocantinsi: a new species from the upper rio Tocantins basin, Central Brazil (Characiformes: Characidae). Neotropical Ichthyology, 8: 247-254.

Ferreira, K. M., N. A. Menezes \& I. Quagio-Grassiotto. 2011. A new genus and two new species of Stevardiinae (Characiformes: Characidae) with a hypothesis on their relationships based on morphological and historical data. Neotropical Ichthyology, 9: 281-298.

Gonçalves, T. K., M. A. Azevedo \& L. R. Malabarba. 2005. Reproductive biology and development of sexually dimorphic structures in Aphyocharax anisitsi (Ostariophysi: Characidae). Neotropical Ichthyology, 3: 433-438.

Javonillo, R., J. R. Burns \& S. H. Weitzman. 2009. Sperm modifications related to insemination, with examples from the Ostariophysi. Pp. 723-763. In: Reproductive biology and phylogeny of fishes (Agnathans and Bony fishes). Phylogeny Reproductive System Viviparity - Spermatozoa. Jamieson, B. G. M. (ed.) Science Publishers, Enfield.

Javonillo, R., L. R. Malabarba, S. H. Weitzman \& J. R. Burns. 2010. Relationships among major lineages of characid fishes (Teleostei: Ostariophysi: Characiformes), based on molecular sequence data. Molecular Phylogenetics and Evolution, 54: 498-511.

Jerep, F. C., F. R. Carvalho \& V. A. Bertaco. 2011. Geographic distribution of Hemigrammus ora (Ostariophysi: Characiformes: Characidae) in the Amazon basin, Brazil. Zoologia, 28: 545-550.

Jerep, F. C. \& L. R. Malabarba. 2011. Revision of the genus Macropsobrycon Eigenmann, 1915 (Characidae: Cheirodontinae: Compsurini). Neotropical Ichthyology, 9: 299-312.

Kutaygil, N. 1959. Insemination, sexual differentiation and secondary sex characters in Stevardia albipinnis Gill. Hidriobiologie, Istanbul Üniversitesi Fen Fakültesi Mecumuasi Seri B, 24: 93-128.

Malabarba, L. R. 1998. Monophyly of the Cheirodontinae, characters and major clades (Ostariophysi: Characidae). Pp. 193-233. In: L. R. Malabarba, R. E. Reis, R. P. Vari, Z. M. S. Lucena \& C. A. S. Lucena (Eds.). Phylogeny and Classification of Neotropical Fishes. Porto Alegre, Brazil: EDIPUCRS, 603p.

Malabarba, L. R. 2003. Subfamily Cheirodontinae (Characins, tetras). p. 215-221. In: R. E. Reis, S. O. Kullander \& C. J. Ferraris Jr. (Org.). Check list of the Freshwater Fishes of South and Central America. Porto Alegre: EDIPUCRS.

Malabarba, L. R. , V. A. Bertaco, F. R. Carvalho \& T. Litz. 2012. Revalidation of the genus Ectrepopterus Fowler (Teleostei: Characiformes), with the redescription of its type species, $E$. uruguayensis. Zootaxa, 3204: 47-60.

Malabarba, L. R., F. C. T. Lima \& S. H. Weitzman. 2004. A new species of Kolpotocheirodon (Teleostei: Characidae: Cheirodontinae: Compsurini) from Bahia, northeastern Brazil, with a new diagnosis of the genus. Proceedings of the Biological Society of Washington, 117: 317-329.

Malabarba, L. R. \& S. H. Weitzman. 1999. A new genus and species of South American fishes (Teleostei: Characidae: Cheirodontinae) with a derived caudal fin, including comments about inseminating cheirodontines. Proceedings of the Biological Society of Washington, 112: 410-431.

Malabarba, L. R. \& S. H. Weitzman. 2000. A new genus and species of inseminating fish (Teleostei: Characidae: Cheirodontinae: Compsurini) from South America with uniquely derived caudal-fin dermal papillae. Proceedings of the Biological Society of Washington, 113: 269-283.
Malabarba, L. R. \& S. H. Weitzman. 2003. Description of a new genus with six new species from Southern Brazil, Uruguay and Argentina, with a discussion of a putative characid clade (Teleostei: Characiformes: Characidae). Comunicações do Museu de Ciências e Tecnologia, PUCRS, Série Zoologia, 16: 67-151.

Menezes, N. A., K. M. Ferreira \& A. L. Netto-Ferreira. 2009a. A new genus and species of inseminating characid fish from the rio Xingu basin (Characiformes: Characidae). Zootaxa, 2167: 47-58.

Menezes, N. A., A. L. Netto-Ferreira \& K. M. Ferreira. 2009b. A new species of Bryconadenos (Characiformes: Characidae) from the rio Curuá, rio Xingu drainage, Brazil. Neotropical Ichthyology, 7: 147-152.

Menezes, N. A. \& S. H. Weitzman. 2009. Systematics of the Neotropical fish subfamily Glandulocaudinae (Teleostei: Characiformes: Characidae). Neotropical Ichthyology, 7: 295-370.

Mirande, J. M. 2009. Weighted parsimony phylogeny of the family Characidae (Teleostei: Characiformes). Cladistics, 2: 574-613.

Mirande, J. M. 2010. Phylogeny of the family Characidae (Teleostei: Characiformes): from characters to taxonomy. Neotropical Ichthyology, 8: 385-568.

Mirande, J. M., G. Aguilera \& M. de las M. Azpelicueta. 2011. A threatened new species of Oligosarcus and its phylogenetic relationships, with comments of Astyanacinus (Teleostei: Characidae). Zootaxa, 2994: 1-20.

Nelson, K. 1964. Behavior and morphology in the glandulocaudine fishes (Ostariophysi: Characidae). University of California Publications Zoology, 75: 59-152.

Oliveira, C., G. S. Avelino, K. T. Abe, T. C. Mariguela, R. C. Benine, G. Ortí, R. P. Vari \& R. M. C. e Castro. 2011. Phylogenetic relationships within the speciose family Characidae (Teleostei: Ostariophysi: Characiformes) based on multilocus analysis and extensive ingroup sampling. BMC Evolutionary Biology 2011, 11:275.

Shrestha, B., R. Javonillo, J. R. Burns \& A. Vertes. 2010. In situ tissue analysis of metabolites, lipids, and proteins in the gill glands of bloodfin tetra by LAESI Mass Spectrometry. Proceedings of the 58th American Society for Mass Spectrometry Conference on Mass Spectrometry and Allied Topics. MP562.

Thomaz, A.T., L. R. Malabarba \& S. L. Bonatto. 2010. The phylogenetic placement of Hollandichthys Eigenmann 1909 (Teleostei: Characidae) and related genera. Molecular Phylogenetics and Evolution, 57: 1347-1352.

Weitzman, S. H. \& S. V. Fink. 1985. Xenurobryconin phylogeny and putative pheromone pumps in glandulocaudine fishes (Teleostei: Characidae). Smithsonian Contributions to Zoology, 421: 1-121.

Weitzman, S. H., N. A. Menezes, H.-G. Evers \& J. R. Burns. 2005. Putative relationships among inseminating and externally fertilizing characids, with a description of a new genus and species of Brazilian inseminating fish bearing an anal-fin gland in males (Characiformes: Characidae). Neotropical Ichthyology, 3: 329-360.

Submitted January 17, 2012 Accepted April 13, 2012 Published June 29, 2012 